ISSN 1991- 8690

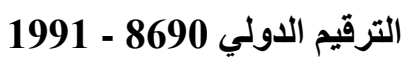

website : http:// jsci.utq.edu.iq

Email: utjsci@utq.edu.iq

\title{
Chemical Content and Antibacterial Activity of Some Extracts of Anastatica hierochuntica leaves
}

\author{
Arwa H. M. AL-Saeed ${ }^{(1)} \quad$ Newres N. Jaber ${ }^{(2)}$ \\ ${ }^{(1)}$ Department of chemistry - College of Science - University of Basra - Basra, Iraq \\ ${ }^{(2)}$ Department of Microbiology - College of Veterinary medicine - University of Basra - Basra, Iraq
}

\begin{abstract}
$\underline{\text { Abstract }}$
The present study was undertaken to study the chemical content and antibacterial activity of Anastatica hierochuntica leaves by preparation extracts (n-hexan, ethanolic 70\% and aqueous) and tested against Grampositive bacteria (Streptococcus pyogens and Staphylococcus aureus) and Gram-negative bacteria (Escherichia coli, Pseudomonas aeruginosa and Proteus vulgaris). The results of chemical analysis showed that hexan extract contains phenols, terpenes and sterols only, while extracts (ethanolic $70 \%$ and aqueous) contain carbohydrates, phenols, flavonoids, tannins, saponins and alkaloids also observed contained this plant on minerals $(\mathrm{Cu}, \mathrm{Zn}$ and $\mathrm{Fe})$ in concentrations $(8.65 \pm 0.30,47.51 \pm 1.31,169.48 \pm 7.11) \mathrm{ppm}$ respectively. The antibacterial activity of the preparation extracts was evaluated using agar well-diffusion method, the results indicated that plant extracts were more active against Gram-negative bacteria than Gram-positive bacteria, alcoholic extract has antibacterial activity stronger than hexan and aqueous extracts. From this results we concluded that Anastatica hierochuntica leaves can used in treatment of various disorders by have a number of active components and antibacterial activity.
\end{abstract}

Key words: Anastatica hierochuntica leaves, antibacterial activity, Chemical Analysis, $\mathrm{Cu}, \mathrm{Zn}, \mathrm{Fe}$

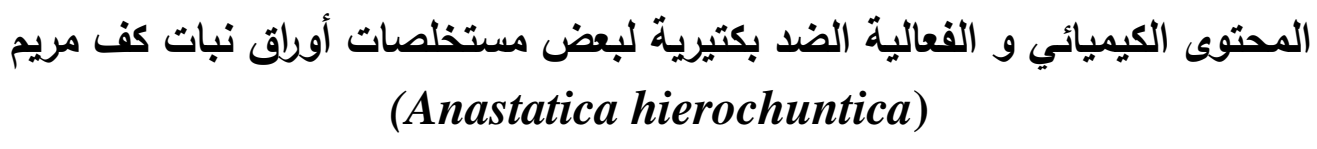

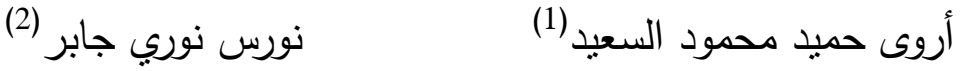

$$
\begin{aligned}
& \text { (1) قسم الكيمياء - كلية العلوم - جامعة البصرة - البصرة، العراق }
\end{aligned}
$$

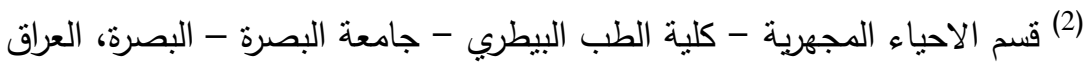

الخلاصة

تم دراسة المحتوى الكيميائي و الفعالية الضد بكتبرية لاوراق نبات كف مريم من خلال تحضير مستخلصات (الهكسان ، الايثانولي 70\% و المائي ) و أختبرت ضد البكتبريا الموجبة لصبغة كرام ( Streptococcus Pyogens و و Staphylococcus aureus و البكتيريا

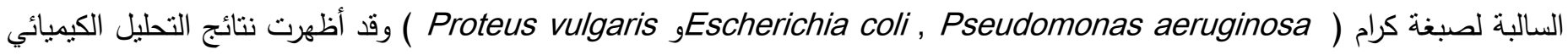




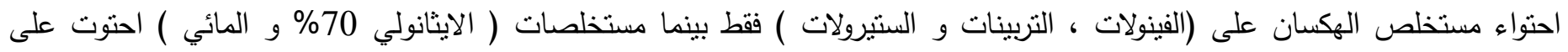

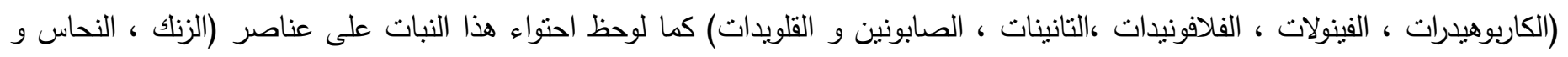

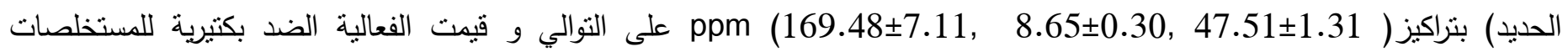
المضرة بأستخدام طريقة الحفر و أظهرت ننائج الدراسة ان مستخلصات النبات اكثر فعالية ضد البكتيريا السالبة لصبغة كرام مقارنة بالبكتيريا

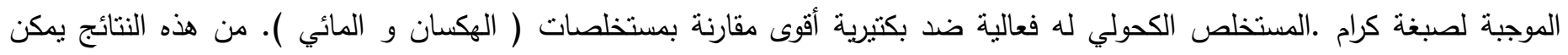

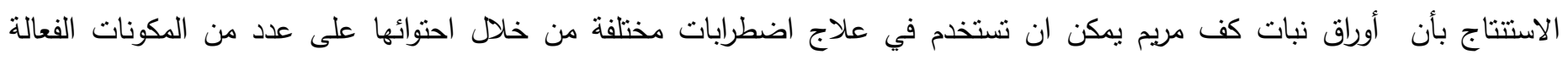
وامتلاكها فعالية ضد بكتبرية .

\section{Introduction}

Anastatica hierochuntica, is a member of the family Brassicaceae [1].Is commonly called "Kaff maryam" or "Rose of Jericho", which is a small grey winter annual herb, found in the arid regions of Saudi Arabia, Egypt, Jordan, Iraq, Kuwait and North Africa [2]. The plant is prescribed in folk medicine for uterine and hemorrhage[3] .It is also used as a tea to treat asthuma and respiratory disease, dysentery, salmonella typhi , typhod fever, diabetes, heart disease and headaches [4].The medicinal value of this plant lie in phytochemical components which produce definite physiological actions on human body [5],so this study was undertaken to find chemical composition of Anastatica hierochuntica leaves and evaluation activity of some plant extracts as antibacterial .

\section{Materials and Methods}

\section{Plant material}

Anastatica hierochuntica was brought from local market of Basra city. The plant was separated into leaves and stems, after that the leaves were washed with tap water and dried at room temperature $\left(25^{\circ} \mathrm{C}\right)$.The dried leaves material was ground to fine powder.

\section{Bacterial strains}

The isolates of bacteria used in this study were obtained from Microbiology Department, College of veterinary medicine, Basra University as shown in table (1).
Table 1: Bacterial strains

\begin{tabular}{|c|c|}
\hline Gram Reaction & Indicator Strain \\
\hline $\begin{array}{c}\text { Gram Positive } \\
\text { bacteria }\end{array}$ & $\begin{array}{c}\text { Staphylococcus aureus } \\
\text { Streptococcus pyogens }\end{array}$ \\
\hline $\begin{array}{c}\text { Gram Negative } \\
\text { bacteria }\end{array}$ & $\begin{array}{c}\text { Escherichia coli } \\
\text { pseudomonas aeruginosa } \\
\text { Proteus vulgaris }\end{array}$ \\
\hline
\end{tabular}

\section{Preparation of Extracts}

n-hexan Extract: $50 \mathrm{gm}$ of Anastatica hierochuntica leaves powder was added to a thimble and then placed in a soxhlet extractor.Heat was applied to a round bottom flask which contain n-hexan solvent was placed at the base of the soxhlet extractor.The extract was concentrated using a rotary evaporator (Puchi Rotavapor-Re) then dried at room temperature [6] .

Alcoholic Extract: The alcoholic extract was prepared by extracting $(50 \mathrm{gm})$ of Anastatica hierochuntica leaves with $70 \%$ ethanol using reflux method. The suspension was filtered through whatman filter paper No. 31, the filtrate was concentrated using rotary evaporator [7].

Aqueous Extract: Aqueous extract was obtained by extracting (50 gm) of Anastatica hierochuntica leaves with deionized distilled water using reflux method. The suspension was filtered through whatman filter paper No. 31, the filtrate was concentrated by rotary evaporator [7]. 


\section{Chemical Analysis}

Phytochemical analysis: Quantitative phytochemical tests were carried out on the preparation extracts using standard procedures to identify the presence or absence of carbohydrates , phenols , flavonoids , tannins , saponins , alkaloids , terpenoids and sterols according to the methods described by [8] and [9] .

Minerals Analysis: Anastatica hierochuntica leaves in the powdred form was weighed and digested in (5:1) mixture of nitric acid and perchloric acid [10] . After digestion few drops of concentrated $\mathrm{HCl}$ was added. The solution was heated and then filtered. The filtrate was diluted suitably with distilled deionized water.The dilute filtrate solution was used for analysis of minerals of interest by atomic absorption spectrophotometer. The measurement of minerals was performed in triplicate at the minimum [11].

Antibacterial Activity: five types of pathogenic bacteria were previously isolated and identified by other work. Muller-Hinton agar medium was used for bacteria growth plates were incubated at $37{ }^{\circ} \mathrm{C}$ for 24-48 hours. The antibacterial activity of $\mathrm{n}$ hexan, alcoholic and aqueous extracts of Anastatica hierochuntica leaves used Agar-Well diffusion method by adding $100 \mu \mathrm{l}$ containing $20 \mu \mathrm{g} / \mathrm{ml}$ from each extract to each well, the extracts were allowed to diffuse into the medium for 1 hour at room temperature, then incubated at $37^{\circ} \mathrm{C}$ for 24 hours, the zone of growth inhibition were measured and recorded in $\mathrm{mm}$ [12]. The control was set up in a same manner except that the extract replaced with n-hexan and 70\% ethanol.

\section{Statiatical analysis}

The results were expressed as mean $\pm \mathrm{SD}$ was performed by ANOVA procedures [13] .

\section{Results and Discussion}

The results of phytochemical analysis of Anastatica hierochuntica leaves are presented in Table 2 which show that contained alcoholic and aqueous extracts on same components carbohydrates, phenols, flavonoids, tannins, saponins and alkaloids while, n-hexan extract contained phenols, terpenoids and sterols as refer [14] .

Table 2: Phytochemical analysis of Anastatica hierochuntica leaves.

\begin{tabular}{|c|c|c|c|}
\hline Phytochemicals & $\begin{array}{c}\text { n- } \\
\text { hexan } \\
\text { extract }\end{array}$ & $\begin{array}{c}\text { Alcoholic } \\
\text { extract }\end{array}$ & $\begin{array}{c}\text { Aqueous } \\
\text { extract }\end{array}$ \\
\hline carbohydrates & - & + & + \\
\hline phenols & + & + & + \\
\hline Flavonoids & - & + & + \\
\hline Tannins & - & + & + \\
\hline Saponins & - & + & + \\
\hline Alkaloids & - & + & + \\
\hline Terpenoids & + & - & - \\
\hline Sterols & + & - & - \\
\hline
\end{tabular}

Absence $=-$, Presence $=+$

The results of minerals analysis revealed that contained Anastatica hierochuntica leaves on copper $(\mathrm{Cu})$, zinc $(\mathrm{Zn})$ and iron $(\mathrm{Fe})$ as shown in Table 3 this result is in agreement with [15] .

Table 3 : Mineral concentration of Anastatica hierochuntica leaves .

\begin{tabular}{|ccc|}
\hline \multicolumn{3}{|c|}{ Minerals (ppm) } \\
\hline $\mathbf{C u}$ & $\mathbf{Z n}$ & Fe \\
$8.65 \pm 0.30$ & $47.51 \pm 1.31$ & $169.48 \pm 7.11$ \\
\hline
\end{tabular}

Data are mean \pm standard deviation, $p$ pm $=$ parts per million (1 mg / Kg = 1 ppm)

In this study we obtained data for minerals concentration were difference than those reported by [15], this may be attributed to the differences in botanical structure, as well as in the mineral composition of the soil in which the plant is cultivated. The presence of these essential minerals implies Anastatica hierochuntica leaves could be utilized as a nutritionally valuble and healthy ingredient. These nutrients may no be strictly medicinal but could be valuable in preventing 
disease that are related to malnutrition. Copper is growth and development but can be toxic at excessive levels [16] .Copper deficiency results in anemia and congenital inability to excrete copper resulting in wilson's disease [17] .

Zinc is an essential trace element for plant growth and also plays an important role in various cell processes including normal growth, brain development, behavioural response, bone formation and wound healing [18]. animals, the role of iron in the body is clearly associated with hemoglobin and the transfer of oxygen from lungs to the tissue cells and is very important factor in diabetes [19].

The antibacterial activity of the crude extracts were assessed quantitatively by determining the zones of inhibition as given in table 4 and figures 1 and 2 .
Iron is an essential element for human beings and

an essential enzymatic element for normal plant

Table 4: Antibacterial activity of n-hexan, ethanolic and aqueous extracts of Anastatica hierochuntica leaves using the well diffusion method.

\begin{tabular}{|c|c|c|c|}
\hline $\begin{array}{c}\text { Test } \\
\text { Organisms }\end{array}$ & \multicolumn{3}{|c|}{ Inhibition Zone (mm) } \\
\hline $\begin{array}{c}\text { Gram-positive } \\
\text { bacteria }\end{array}$ & $\begin{array}{c}\text { n- } \\
\text { hexan } \\
\text { Extract }\end{array}$ & $\begin{array}{c}\text { ethanolic } \\
\text { Extract }\end{array}$ & $\begin{array}{c}\text { Aqueous } \\
\text { Extract }\end{array}$ \\
\hline $\begin{array}{c}\text { Streptococcus } \\
\text { pyogens }\end{array}$ & 17 & 20 & 0 \\
\hline $\begin{array}{c}\text { Staphylococcus } \\
\text { aureus }\end{array}$ & 23 & 28 & 0 \\
\hline $\begin{array}{c}\text { Gram-negative } \\
\text { bacteria }\end{array}$ & 35 & 35 & 9 \\
\hline Escherichia coli & 29 & 29 & 17 \\
\hline $\begin{array}{c}\text { Pseudomonas } \\
\text { aeruginosa }\end{array}$ & 25 & 27 & 15 \\
\hline $\begin{array}{c}\text { Proteus } \\
\text { vulgaris }\end{array}$ & & & \\
\hline
\end{tabular}

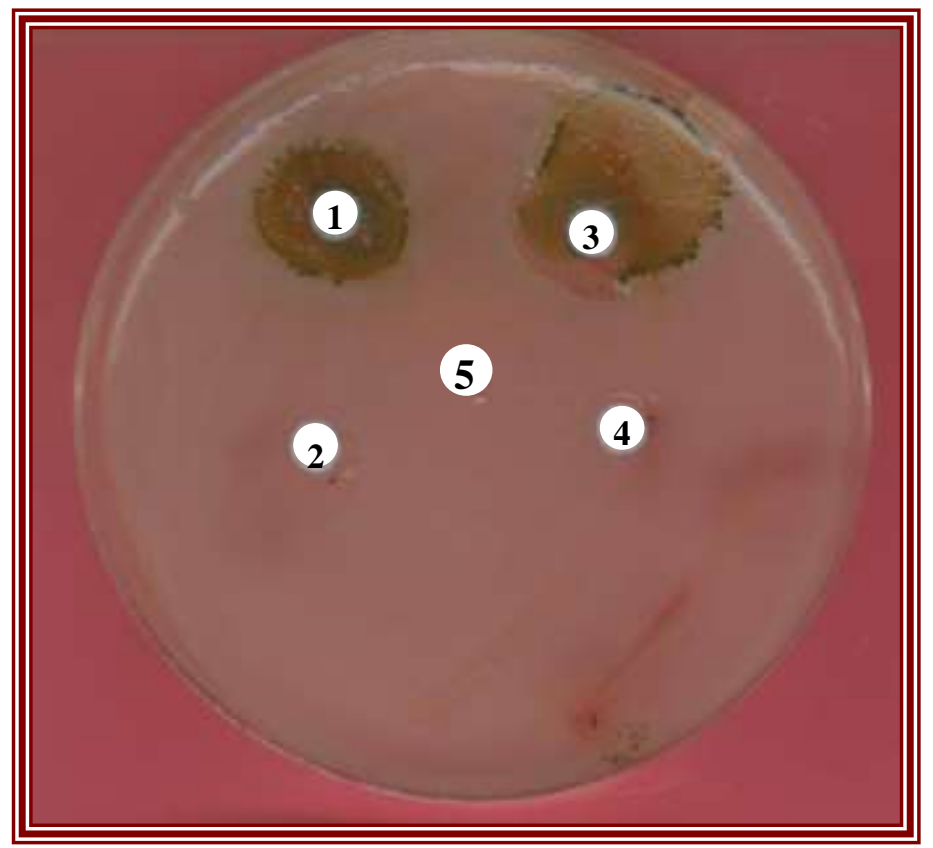

Streptococcus pyogens

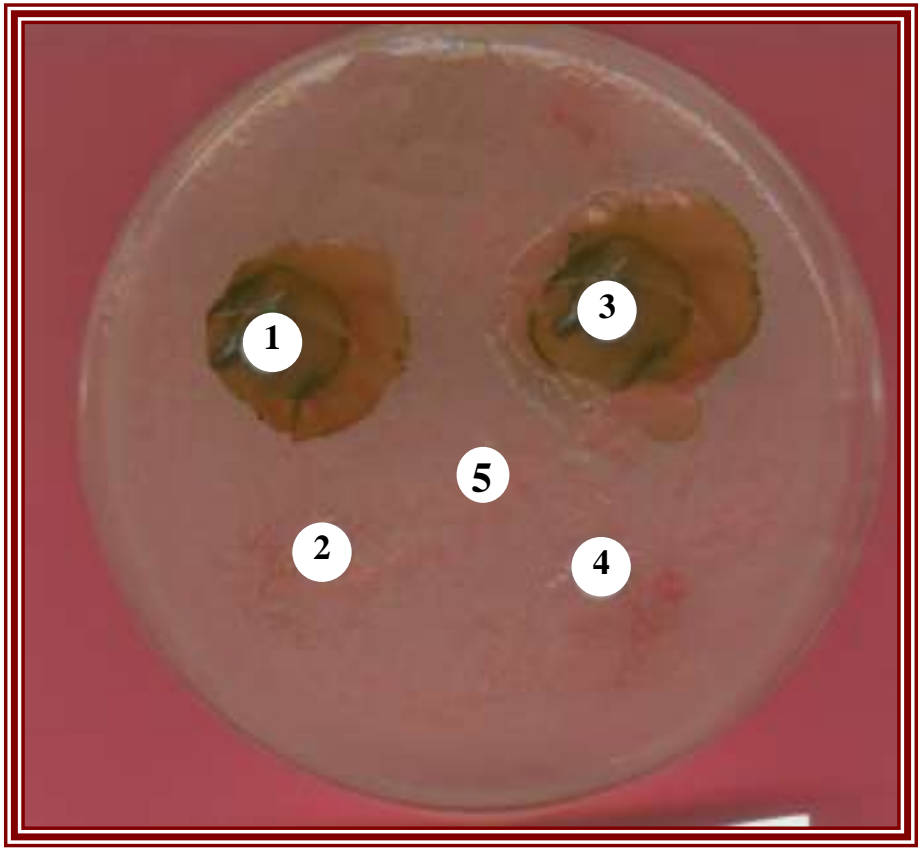

Staphylococcus aureus

Figure 1: Antibacterial activity of n-hexan, ethanolic and aqueous extracts of Anastatica hierochuntica leaves against Grampositive bacteria.

1-n-hexan extract $\quad$ 2- aqueous extract $\quad$ 3- ethanolic extract $\quad$ 4- n- hexan 5- ethanolic 70\% 


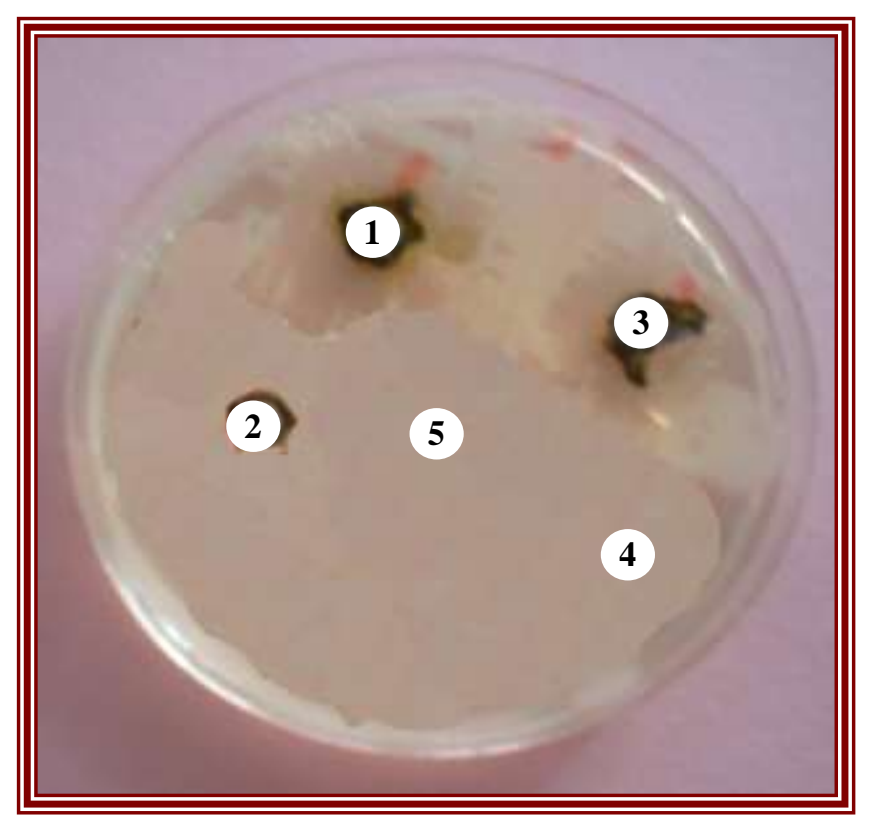

Escherichia coli

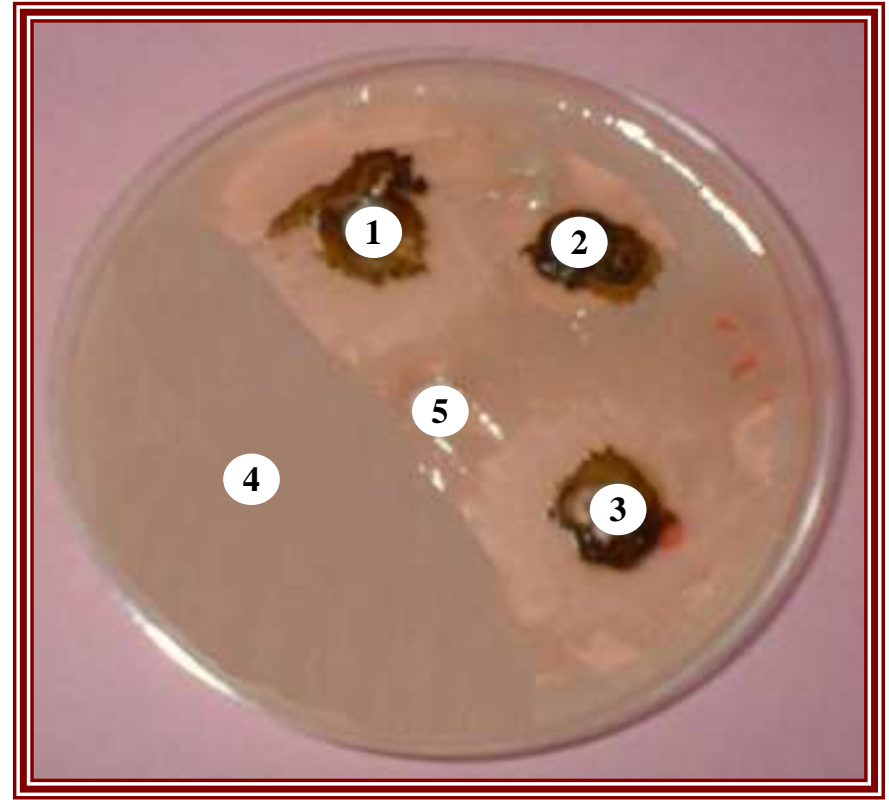

Pseudomonas aeruginosa

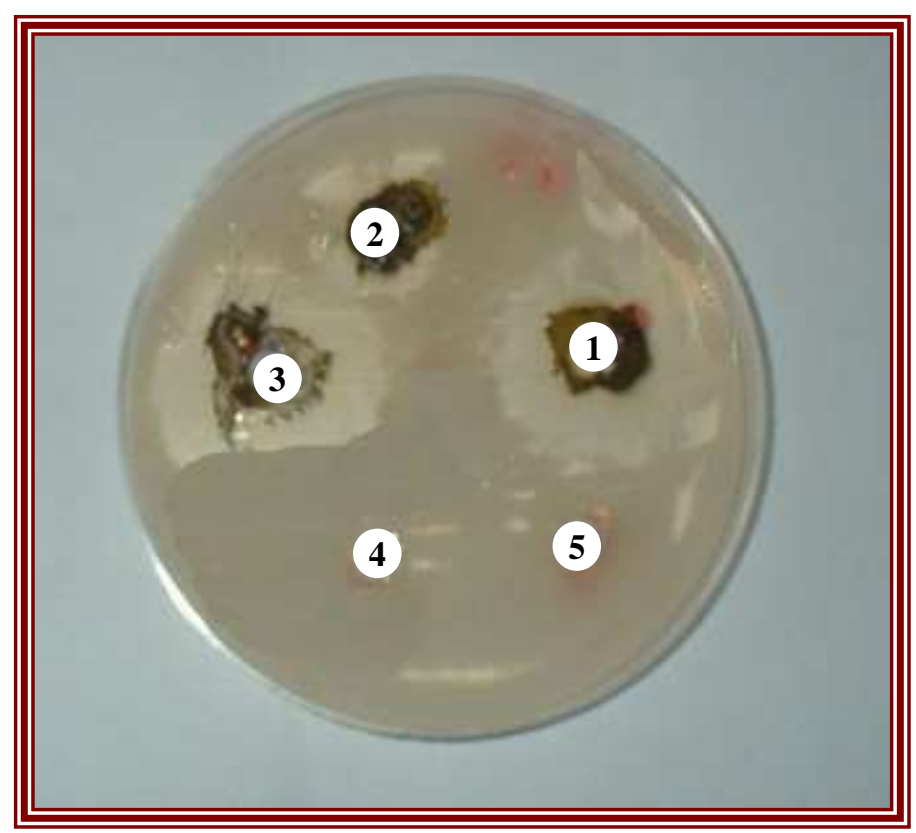

\section{Proteus vulgaris}

Figure 2: Antibacterial activity of n-hexan, ethanolic and aqueous extracts of Anastatica hierochuntica leaves against Gram-negative bacteria .
1- n-hexan extract
2- aqueous extract
3- ethanolic extract
4- n- hexan
5- ethanolic 70\% 
The n-hexan and alcoholic crude extracts of Anastatica hierochuntica leaves showed variable inhibition effects against both the Gram-positive bacteria (Streptococcus pyogens and Staphylococcus aureus ) and Gram-negative bacteria (Escherichia coli, Pseudomonas aeruginosa and Proteus vulgaris ) as compared with control. While aqueous extract showed antibacterial activity against Gram-negative bacteria only. In general, ethanolic extract has antibacterial activity as compared with control this result may be due to these types of bacteria not sensitive for this concentration of alcohol. Ethanolic extract on the other hand showed stronger inhibition effect than n-hexan and aqueous extracts. This suggests that some of the active compounds in the ethanolic extract exist in higher percent than those in n-hexan and aqueous extracts. Previous studies have noted alcohols to be reliable and consistent solvents for the extraction of antimicrobial substances from medicinal plants [20], the n-hexan extract may contain non-polar compounds that inhibits the growth of bacteria, they might have novel bioactive phytochemical compounds present in low concentration.

The potency of Anastatica hierochuntica leaves as antibacterial is attributed to the action of phytochemical compounds is contains, which are secreted by plant naturally, in response to environmental pressure or as a defense mechanism to animal attacks or plant diseases, these compounds normally extracted in polar extracts included alkaloids, flavonoids and some phenls, or non-polar compounds may include terpenes and sterols. Antibacterial activity may involve complex mechanisms, like the inhibition of the synthesis of cell walls and cell membranes and proteins [21]. This results help to explain the therapeutic effect of the plant.

\section{Referenes}

1. Wickens, G. E. (1998). Ecophysiology of Economic olants in Arid and semi-arid Lands. Spinger. p. 343. ISBN-3-540-521712. pages 204-205.
2. El-Ghazali, G.E. , Al-Khlifa, K.S. , Saleem, G.A. and Abda allah, E.M. (2010). Traditional medicinal plants indigenous to Al-Rass province, Saudi Arabia. J.Med. plant. Res. , 4 : 2680-2683.

3. Khalifa, T.I. and Ahmad, M.A. (1980). Pharmacognostical study of certain species of Anastatica. Ph.D. thesis, University of Cairo, Egypt.

4. Eman, A.S., Tailang, M., Benyounes, S., Gauthaman, K. (2011). Antimalarial and hepatoprotective effects of entire plants of Anastatica hierochuntica .Int. J. Res. Phytoch. Pharm. , 1: 24-27.

5. Shariff, Z.U. (2001). Modern herbal therapy for common Ailments naturepharmacy series vol.1 spectrum books LTd., Ibadan, Nigeria in association with safari books (Export) Ltd. UK., pp.9-84.

6. Barriada-Pereira, M., Concha-Grana, E., Gonzalez-Castro, m.J., Muniategui-Lorenzo, S., Lopez-Mahia, P., Prada-Rodriguez, D. and Fernandez-Fernandez, E. (2003). Microwave assisted extraction versus soxhlet extraction in the analysis of 21 organochlorine pesticides in plants. Elsevier B. V. J. Chromatogr. 1008: 115-122.

7. Asuzu, I.U. (1986). Pharmacological evaluation of folkore of sphenostylic slenocarpa. Journal Ethanopharmacol. 16, 236-267.

8. Harborn, B.I. (1984). Phytochemical methods: Aguide to modern technology of plants analysis. $2^{\text {nd }}$ Edn., New York, Chapman and Hall, pp: 88-185.

9. Odebedy, O. and Sofowora, A. (1978).Phytochemical screening of Nigerian medicinal plants. LIoydia. 41: 41-234.

10. Herber, R.F.M. and Stoeppler, M. (1994). Trace element anslysis in biological specimens. Elsevier, New York.

11. AoAc. (1990). Official methods of analysis, Association of official analytical chemists, Washington, D.C., USA.15 ${ }^{\text {th }}$ Edition, pp.807928.

12. Perez, C., Pauli, M. and Bazerque, P.(1990) . An antibiotic assay by agar-well diffusion 
method. Acta.Biologiae et medicine experimentaalis, 15:113-115.

13. SPSS Statistical Packages for the Social Sciences. (2001). Statistical soft ware for windows version 13.0 Microsoft. SPSS, Chicago, IL, USA.

14. Mohamed, M.K., Guergues, S.N. and AbdelRahim, E.A. (2000). Studies on the phytochemistry and antimicrobial activity of four plant species from Egypt.Egyption Journal of Microbiology. 35(2) :257-271.

15. Ihsanullah, D. (2012) . Chemical properties of the medicinal herb Kaff Maryam and its relation to folk medicine use .African Journal of Microbiology Res. 6(23): 5048-5051.

16. Kaplan, L.A., Pesce, A.J. and Kazmierczak, S.C. (1993). Theory, analysis, correlation In: Clinical chemistry. $4^{\text {th }}$ Ed. Published by Mosby. 707.

17. Gupta,U. (1975). Copper in the environment In J.O. Nariagu(ed)., John Wiley and Sons , New York. 255.

18. Hunt, J.R. (1994). Bioavailability of Fe, $\mathrm{Zn}$ and other trace minerals for vegetarian Diets.Am.J.Clin.Nutr.78 : 633-39.

19. Sigel, H. (1978). Metals in biological systems .Marcel Dekker, New York.

20. Ahmad, I., Mehmood, Z. and Mohammad,f. (1998). Screening of some Indian medicinal plants for their antimicrobial properties. J.Ethnopharmocol. 62: 183-193.

21. Oyaizu, M., Fujimoto, Y., Ogihara,H., Sekimoto,K., Naruse,A., Naruse,U. (2003). Antioxidative and antimicrobial activities extracts from several utility plants.Food preservation Science. 29 : 33-38. 